\title{
Chromium carbochelate dietary supplementation favored the glucocorticoid response during acute inflammation of Piaractus mesopotamicus
}

\author{
Marcello Pardi de Castro a , Gustavo Silva Claudiano a , Neida Lucas Bortoluzzi ${ }^{a}$, Eduardo Garrido ${ }^{\text {a }}$, \\ Rodrigo Yudi Fujimoto ${ }^{\mathrm{b}}$, Marco Antônio Andrade Belo ${ }^{\mathrm{a}, \mathrm{c}}$, Marina Tie Shimada ${ }^{\mathrm{a}}$, \\ Julieta Rodini Engracia Moraes ${ }^{\text {a }}$, Flávio Ruas Moraes ${ }^{\text {a,* }}$ \\ a Department of Veterinary Pathology, São Paulo State University (Unesp), Jaboticabal, Brazil \\ ${ }^{\mathrm{b}}$ Researcher from Brazilian Agricultural Research Corporation-EMBRAPA, Sergipe, Brazil \\ c Laboratory of Animal Pharmacology and Toxicology, Camilo Castelo Branco University, Brazil
}

\section{A R T I C L E I N F O}

\section{Article history:}

Received 26 February 2014

Received in revised form 23 April 2014

Accepted 29 April 2014

Available online 9 May 2014

\section{Keywords:}

Aeromonas hydrophila

Insulin

Cortisol

Chromium

Teleost

\begin{abstract}
A B S T R A C T
This study was performed to investigate the effect of food supplementation with chromium carbochelate on cortisolemia, glycemia and unspecific acute inflammation of pacus (Piaractus mesopotamicus) challenged by inactivated Aeromonas hydrophila in the swim bladder. 120 pacus $(80.5 \pm 11.3 \mathrm{~g})$ were randomly distributed into 24 tanks ( $310 \mathrm{~L}, \mathrm{n}=5$ ). After the adaptation period, the pacus were fed diets supplemented with 0 (control), 12,18 and $36 \mathrm{mg}$ of chromium carbochelate/kg of dry diet for 90 days (ad libitum). Fish fed diets containing 18 and $36 \mathrm{mg}$ of $\mathrm{Cr} \cdot \mathrm{kg}^{-1}$ resulted in a reduction of cortisolemia and glycemia, and in an increase in the inflammatory response, seen through the greater accumulation of lymphocytes and thrombocytes. These results together suggest that food supplementation with chromium carbochelate, at the concentrations of 18 and $36 \mathrm{mg} \cdot \mathrm{kg}^{-1} \mathrm{of}$ feeds, brought homeostatic benefits to P. mesopotamicus. These benefits were translated, at least partially, as reductions in the consequences from inflammatory stress, with diminished cortisolemia and glycemia, which favored accumulation of lymphocytes and thrombocytes at the affected focus, as an increase in the immune response.
\end{abstract}

(C) 2014 Elsevier B.V. All rights reserved.

\section{Introduction}

Trivalent chromium intensifies the action of insulin (Mowat, 1997) and reduces the plasma concentration of cortisol in stress situations (Wedemeyer, 1997). The glucocorticoids in high concentrations cause suppression of the inflammatory response (Belo et al., 2005, 2012). On the other hand, trivalent chromium is a glucose tolerance factor (Mowat, 1997), which facilitates the chemical interaction of the insulin with its receptor on cell membranes, thus increasing the sensitivity of the cell to glucose (Fujimoto et al., 2005; Lukaski, 2000; Mertz and Roginski, 1969).

In acute inflammation in Wistar mice induced by carrageenan, insulin and adrenal corticosteroids have antagonistic physiological effects. In the initial phase of the reaction, the properties of insulin provide glucose as the energy source needed for inflammation to develop. $2 \mathrm{~h}$ after the inflammatory stimulus, the plasma corticosterone concentration will

\footnotetext{
* Corresponding author at: Via de Acesso Prof. Paulo Donato Castellane, s/n Rural, CEP 14884-900 Jaboticabal, Brazil. Tel.: + 5516997852072.

E-mail address: fruasmoraes@gmail.com (F.R. Moraes).
}

be more than twice as great as the initial value, resulted by the stimulation of the hypothalamus-hypophysis-adrenal axis, in the sense of limiting the development of the reaction (Moraes and Garcia-Leme, 1982; Moraes et al., 1987). Prado (2014) proved the same antagonistic effect in alloxan-diabetic tilapia submitted to insulin and dexamethasone treatments. Therefore, chromium might act as a boosting agent for insulin action and a glucose tolerance factor, both towards limiting cortisol release (Fujimoto et al., 2005) and favoring the inflammatory response (Castro et al., 2014a), since this hormone participates in the glucose transport mechanism across the cell membrane. The increment in the fish inflammatory response would be useful in defense against infectious agents.

According to Castro et al. (2014a), few studies have analyzed the effect of trivalent chromium on the inflammatory response of fish or the possible effect produced by the interaction of dietary supplementation. Although the intake level of specific nutrients can determine better organic responses and crowding stress can increase disease outbreaks, few concomitant changes in the immunological parameters have been observed on these occasions (Belo et al., 2012, 2014; Garcia et al., 2007; Salvador et al., 2012). The pacu (Piaractus mesopotamicus), an emergent species in the world of aquaculture, is a native teleost fish of 
the Parana-Paraguay Basin, and is of importance in the South America for human consumption, angling and aquaculture (Belo et al., 2005). The pacu has proven to be a good bioindicator of water quality, and in accordance with Castro et al. (2014b) this species has been used in ecotoxicity studies for registration of chemicals in Brazil. With this in mind, an in vivo study was performed to investigate the effect of food supplementation with chromium carbochelate on cortisolemia, glycemia and unspecific acute inflammation of pacus inoculated with inactivated Aeromonas hydrophila in the swim bladder.

\section{Material and methods}

\subsection{Experimental design}

A total of 120 pacus (P. mesopotamicus), male and female, originating from the same spawn, weighing $80.5 \pm 11.3 \mathrm{~g}$ were used. These were distributed into 24 plastic tanks ( $310 \mathrm{~L}, \mathrm{n}=5$ ) that were supplied with chlorine-free running water at a flow rate of $1 \mathrm{~L} / \mathrm{min}$., in a recirculation system. Initially, the fish were acclimated for 15 days, receiving commercial feed without chromium. After the adaptation period, the pacus were fed diets supplemented with chromium carbochelate for 90 days, ad libitum. One group remained as an unsupplemented control. The quality of the water was maintained as follows: dissolved oxygen $5.7 \pm 0.1 \mathrm{mg} \cdot \mathrm{L}^{-1}$, temperature $28.4 \pm 0.8{ }^{\circ} \mathrm{C}$, potential of hydrogen ions $(\mathrm{pH}) 7.7 \pm 0.4$, and electric conductivity $192.4 \pm$ $3.6 \mu \mathrm{S} \cdot \mathrm{cm}^{-1}$ (Boyd, 1990).

\subsection{Diets}

Table 1 expresses the percentage and chemical-bromatological composition of the baseline feed (26\% crude protein and $3800 \mathrm{kcal}$ gross energy) to which the chromium carbochelate $(\mathrm{Cr})$ was incorporated, at concentrations of $0,12,18$ and $36 \mathrm{mg}$ of chromium carbochelate per $\mathrm{kg}$ of feed (Fujimoto et al., 2005, 2007, 2011). The feeds were pelletized, packed and stored at $-18{ }^{\circ} \mathrm{C}$. The fish received feed twice a day (ad libitum), with water flow interrupted and aeration added to provide suitable conditions for feeding time. Samples of $50 \mathrm{~g}$ of each diet were taken to determine the $\mathrm{Cr}$ concentrations through plasma induction spectrophotometry (ICP-OES, GBC Integra XM).

\subsection{Induction of aerocystitis}

Inactivated $A$. hydrophila were used as inflammatory stimulation. The bacterium was isolated from naturally infected fish. The titer of

Table 1

Percentage and chemical-bromatological composition of the experimental diet.

\begin{tabular}{ll}
\hline Ingredients & $\%$ \\
\hline Fish flour & 13 \\
Soy bran & 23 \\
Wheat bran & 21 \\
Ground corn (maize) & 25 \\
Rice bran & 16 \\
Crude soybean oil & 1 \\
Vitamin and mineral supplement (kg/product) & 1 \\
Analyzed composition & \\
Crude protein (\%) & 26 \\
Ether extract (\%) & 6.23 \\
Crude fiber (\%) & 6.25 \\
Gross energy (kcal/kg of feed) & 3900 \\
Ca:P ratio & $1.45: 1$ \\
\hline
\end{tabular}

Composition of the mineral and vitamin supplements (nutrient $/ \mathrm{kg}$ ): iron 15,000 mg, copper $5000 \mathrm{mg}$, iodine $500 \mathrm{mg}$, manganese $17,000 \mathrm{mg}$, zinc $12,000 \mathrm{mg}$, selenium $70 \mathrm{mg}$, vehicle $1000 \mathrm{mg}$, vitamin A 12,000 UI, vitamin D3 1500 UI, vitamin E $50 \mathrm{mg}$, ascorbil 2-poliphosphate $200 \mathrm{mg}$, vitamin K $4 \mathrm{mg}$, vitamin B12 $7 \mathrm{mg}$, vitamin B2 $7 \mathrm{mg}$ pantothenic acid $60 \mathrm{mg}$, nicotinic acid $120 \mathrm{mg}$, choline chloride $600 \mathrm{mg}$, methionine $700 \mathrm{mg}$ and antioxidant $500 \mathrm{mg}$. For the control ration, $18 \mathrm{mg}$ of kaolin/ $\mathrm{kg}$ of feed was included, thus replacing the $\mathrm{Cr}$. the inoculum was determined through bacterial counting with 4'6-diamino-2-phenylindole (DAPI). It was diluted in PBS to have $3 \times 10^{9} \mathrm{CFU} \cdot \mathrm{mL}^{-1}$, and was inactivated by means of a water bath at $40{ }^{\circ} \mathrm{C}$ for $30 \mathrm{~min}$. (Popoff, 1984). An aliquot was plated in a medium appropriate for certification of bacterial inactivity.

After the supplementation period, the fish were anesthetized in benzocaine solution $(1: 20,000)$ diluted in $98 \%$ alcohol $\left(0.1 \mathrm{~g} \cdot \mathrm{mL}^{-1}\right)$ (Sakabe et al., 2013), to apply the bacterial stimulation (Ethics committee no. 017900-08) into swim bladder. The swim bladder is a cavitary organ, delimited, with terminal circulation and facilities for inoculation and exudate collection for evaluation of the cellular and fluid components accumulated in the inflammatory focus and has no resident leukocytes (Claudiano et al., 2013; Reque et al., 2010). The choice of swim bladder for this assay was due to the advantage of low influence of contamination by other organs during the application of irritant as emphasized by Martins et al. (2009).

\subsection{Blood samples}

At the times of 6, 24 and 48 h post-stimulus (HPS) the stimulus to the swim bladder, groups of fish $(n=5)$ were killed through deep anesthesia and cortisolemia were determined through radioimmunoassay (Gazola et al., 1996) and glycemia using a portable glucometer ("AccuChek® Advantage II", Roche), on total blood samples collected from the caudal vein in the aforementioned times.

\subsection{Evaluation of inflammatory exudate}

The inflammation was evaluated through differential counting of the cells accumulated at the inflamed focus (Martins et al., 2008, 2009). The swim bladder was washed with $0.5 \mathrm{~mL}$ of PBS with $0.09 \%$ EDTA, and the exudate was collected for total and differential counting of cells from the inflammation (Bozzo et al., 2007; Reque et al., 2010). The interior of the swim bladder was washed with complete phosphate buffered saline containing $0.01 \mathrm{~mL}$ EDTA $5 \%$ and cell suspensions were centrifuged at $150 \times g$ for 10 min before staining. The total number of cells was determined with a hemocytometer. Smears were made on microscope slides, air-dried, fixed and stained with Giemsa or periodic acid of Schiff (PAS). From the smears the percentages of macrophages, lymphocytes, granulocytes and thrombocytes were determined to obtain relative and absolute counts of each cell type (Belo et al., 2013).

\subsection{Statistical analysis}

All data was statistically analyzed using a factorial scheme $(4 \times 2$ $\times 3)$ [four levels of $\mathrm{Cr}\left(0,12,18\right.$ and $\left.36 \mathrm{mg} \cdot \mathrm{kg}^{-1}\right)$ and two stimuli inoculated into the swim bladder $(0.5 \mathrm{~mL}$ of $0.65 \%$ sterilized saline solution as the control, and $3 \times 10^{9} \mathrm{CFU}$ of $A$. hydrophila carried in $0.5 \mathrm{~mL}$ of $0.65 \%$ saline solution) and three periods of analysis (6, 24 and 48 h-post stimulus)], according to Littell et al. (1998). The analysis of variance for comparing the different experimental groups was carried out by applying a General Linear Model (GLM) Procedure (SAS, 2001). Significant differences $(p<0.05)$ were estimated on the basis of Tukey's test (Snedecor and Cochran, 1974).

\section{Results}

\subsection{Cortisol}

Fig. $1 \mathrm{~A}$ presents the results from the cortisolemia determinations and shows that fish fed diets containing 18 and $36 \mathrm{mg} \mathrm{of} \mathrm{Cr} \cdot \mathrm{kg}^{-1}$ of diet presented better response profiles for cortisol levels throughout the entire study, including no significant differences ( $p>0.05$ ) were observed among the different experimental periods in pacus supplemented with $18 \mathrm{mg} \mathrm{Cr} \cdot \mathrm{kg}^{-1}$. On the other hand, control animals showed significant increase $(\mathrm{p}<0.05)$ of cortisol levels 6 and 24 HPS. The 

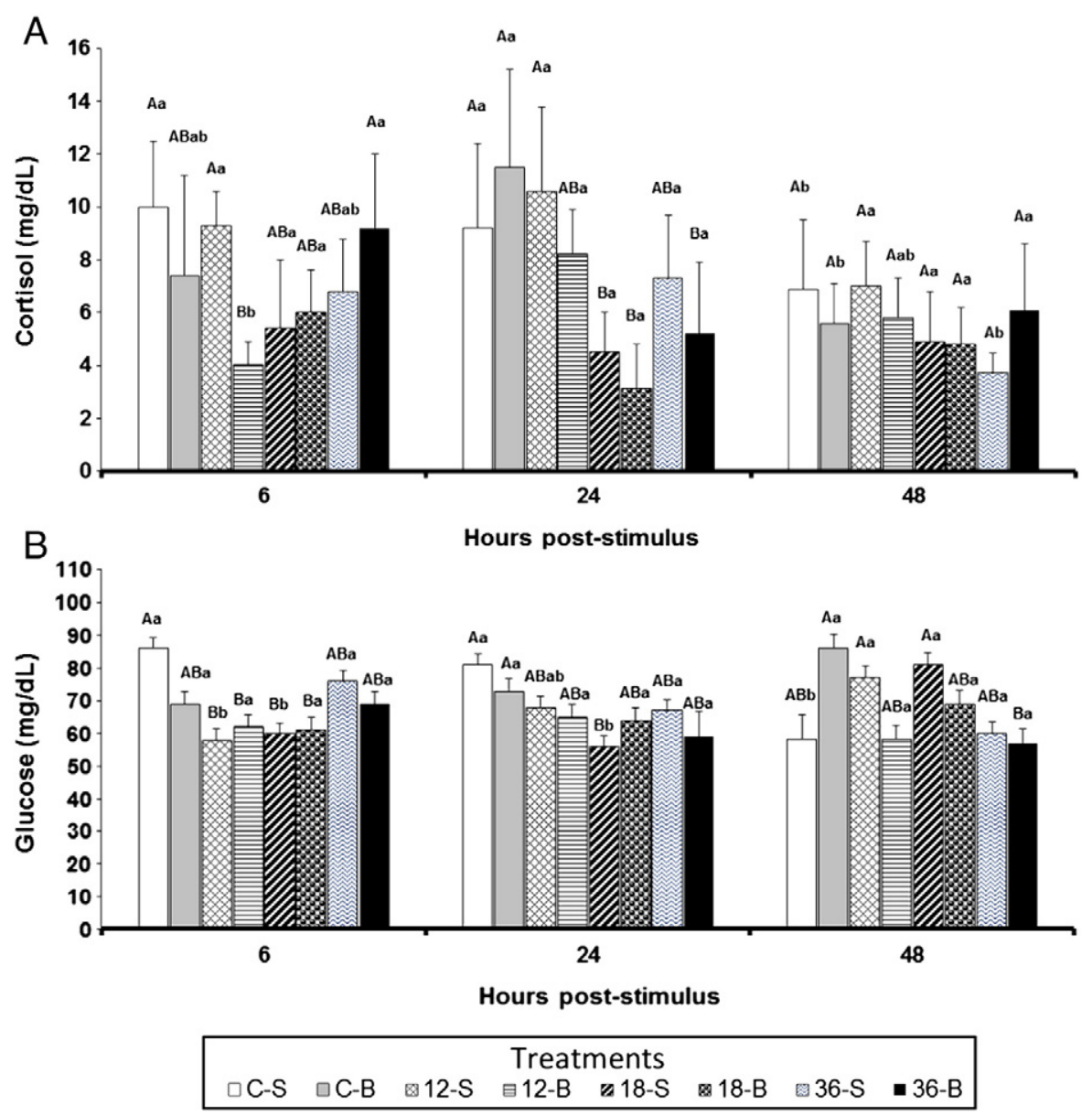

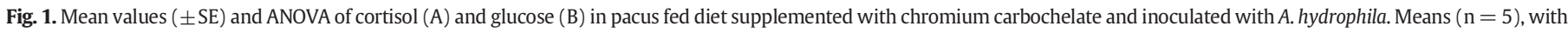

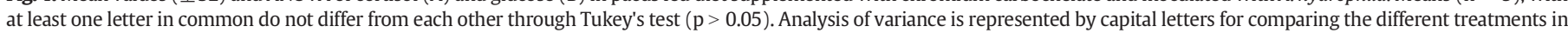

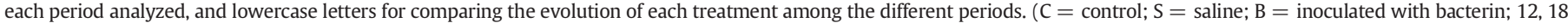
and $36=$ levels of chromium carbochelate in $\mathrm{mg} \cdot \mathrm{kg}^{-1}$ ).

response profile of fish fed $12 \mathrm{mg} \mathrm{Cr} \cdot \mathrm{kg}^{-1}$ was similar to the control animals, except for fish inoculated with the bacterium which presented lower cortisolemia $(\mathrm{p}<0.05) 6$ HPS.

\subsection{Glycemia}

Pacus fed diets supplemented with 12 and $18 \mathrm{mg}$ of $\mathrm{Cr} \cdot \mathrm{kg}^{-1}$ presented significant $(\mathrm{p}<0.05)$ variations in blood glucose levels among the periods (Fig. 1B). While fish controls showed a significant increase $(\mathrm{p}<0.05)$ in glucose levels 6 and 24 HPS in animals inoculated with saline and 48 HPS in pacus inoculated with A. hydrophila. Pacus fed diets supplemented with 12 and $18 \mathrm{mg}$ of $\mathrm{Cr} \cdot \mathrm{kg}^{-1}$ presented significant $(\mathrm{p}<0.05)$ decrease in blood glucose levels when compared to saline control 6 HPS (Fig. 1B). Fish fed diet containing 18 and $36 \mathrm{mg}$ of $\mathrm{Cr} \cdot \mathrm{kg}^{-1}$ and inoculated with $A$. hydrophila showed significant $(p<0.05)$ decrease in blood glucose levels 24 and 48 HPS, respectively (Fig. 1B).

\subsection{Exudate}

The count of total cells accumulated in the exudate showed significant increase $(\mathrm{p}<0.05)$ in fish inoculated with bacterin and fed diet containing $18 \mathrm{mg}$ of $\mathrm{Cr} \cdot \mathrm{kg}^{-1}$ (24 HPS) and $36 \mathrm{mg} \mathrm{of} \mathrm{Cr} \cdot \mathrm{kg}^{-1}$ (6 and 48 HPS). These results were totaling influenced by lymphocyte and thrombocyte counts (Table 2). Regarding the counts of lymphocytes accumulated at the inflammatory focus, at $6 \mathrm{~h}$ after stimulation, the fish that did not receive supplementation did not differ $(p>0.05)$ from the groups that received different stimuli (Table 2). At 24 and 48 $\mathrm{h}$ after stimulation, the number of lymphocytes was greater $(\mathrm{p}<0.05)$ in the groups inoculated with the bacterium than in those injected with saline solution, at concentrations of 18 and $36 \mathrm{mg} \mathrm{Cr} \cdot \mathrm{kg}^{-1}$, respectively, and there were differences $(\mathrm{p}<0.05)$ between the other treatments at the same times (Table 2).

Table 2 shows that among the supplemented fish at $6 \mathrm{~h}$ after stimulation, those inoculated with bacterium presented greater accumulation $(p<0.05)$ of thrombocytes at the concentrations of 18 and $36 \mathrm{mg}$ $\mathrm{Cr} \cdot \mathrm{kg}^{-1}$ than in those injected with saline solution. At this time, the fish injected with saline solution did not differ from each other $(\mathrm{p}>0.05)$, and this continued during the process. At $24 \mathrm{~h}$ after stimulation, the number of thrombocytes was greater $(p<0.05)$ in the group supplemented with $18 \mathrm{mg} \mathrm{Cr} \cdot \mathrm{kg}^{-1}$ and inoculated with bacterium than in the saline solution. The counts on other cell types did not present any significant difference between the groups ( $p>0.05$, Table 2$)$.

\section{Discussion}

Increased plasma cortisol concentration is a stress indicator in teleost fish (Barton and Iwama, 1991; Belo et al., 2005, 2012). The release time and the amount of cortisol released vary between different fish species and with the type of stimulus applied (Belo et al., 2005, 2012; Mommsen et al., 1999). In farming systems, fish are subjected to various types of environments, diets and stressful procedures that affect the physiological balance. 
Table 2

Mean values, transformed in $\log (x+1)$, and ANOVA for total and differential cell counts present in exudate of pacus supplemented with chromium carbochelate and inoculated with A. hydrophila.

\begin{tabular}{|c|c|c|c|c|c|c|c|}
\hline \multirow[t]{3}{*}{ Variables } & \multirow[t]{3}{*}{ Diets (mg/kg) } & \multicolumn{6}{|c|}{ Observation time } \\
\hline & & \multicolumn{2}{|l|}{$6 \mathrm{HPS}$} & \multicolumn{2}{|c|}{$24 \mathrm{HPS}$} & \multicolumn{2}{|c|}{48 HPS } \\
\hline & & $S$ & B & $\mathrm{S}$ & B & $S$ & B \\
\hline \multirow[t]{4}{*}{ Total cells } & Control & $4.4^{\text {Aab }}$ & $5.0^{\mathrm{Aa}}$ & $2.0^{\mathrm{Ab}}$ & $3.8^{\mathrm{Bab}}$ & $7.2^{\mathrm{Aa}}$ & $6.0^{\mathrm{Ba}}$ \\
\hline & 12 & $4.8^{\mathrm{Aa}}$ & $6.0^{\mathrm{Aa}}$ & $2.0^{\mathrm{Aa}}$ & $3.4^{\mathrm{Ba}}$ & $4.2^{\mathrm{Aa}}$ & $5.6^{\mathrm{Ba}}$ \\
\hline & 18 & $2.6^{\mathrm{Abc}}$ & $6.0^{\text {Aab }}$ & $1.4^{\mathrm{Ac}}$ & $10.4^{\mathrm{Aa}}$ & $3.4^{\mathrm{Ab}}$ & $4.0^{\mathrm{Bb}}$ \\
\hline & 36 & $4.0^{\text {Aab }}$ & $7.8^{\mathrm{Aa}}$ & $2.8^{\mathrm{Ab}}$ & $4.2^{\mathrm{Bab}}$ & $5.2^{\text {Aab }}$ & $8.6^{\mathrm{Aa}}$ \\
\hline \multirow[t]{4}{*}{ Lymphocytes } & Control & $3.2^{\mathrm{Aa}}$ & $3.2^{\mathrm{Aa}}$ & $0.6^{\mathrm{Ab}}$ & $1.2^{\mathrm{Bab}}$ & $3.6^{\mathrm{Aa}}$ & $3.0^{\mathrm{Ba}}$ \\
\hline & 12 & $3.2^{\mathrm{Aa}}$ & $4.4^{\mathrm{Aa}}$ & $0.6^{\mathrm{Ab}}$ & $1.2^{\mathrm{Bab}}$ & $1.6^{\text {Aab }}$ & $3.6^{\mathrm{Ba}}$ \\
\hline & 18 & $1.0^{\mathrm{Ab}}$ & $2.8^{\mathrm{Ab}}$ & $0.4^{\mathrm{Ab}}$ & $5.8^{\mathrm{Aa}}$ & $14^{\mathrm{Ab}}$ & $2.8^{\mathrm{Bb}}$ \\
\hline & 36 & $2.8^{\text {Aab }}$ & $1.2^{\mathrm{Ab}}$ & $1.6^{\mathrm{Ab}}$ & $1.6^{\mathrm{Bb}}$ & $3.6^{\text {Aab }}$ & $6.0^{\mathrm{Aa}}$ \\
\hline \multirow[t]{4}{*}{ Thrombocytes } & Control & $1.2^{\text {Aab }}$ & $1.4^{\mathrm{Bab}}$ & $0.8^{\mathrm{Ab}}$ & $2.6^{\mathrm{Ba}}$ & $3.2^{\mathrm{Aa}}$ & $2.8^{\mathrm{Aa}}$ \\
\hline & 12 & $1.2^{\mathrm{Aa}}$ & $1.6^{\mathrm{Ba}}$ & $1.0^{\mathrm{Aa}}$ & $2.2^{\mathrm{Ba}}$ & $2.6^{\mathrm{Aa}}$ & $2.0^{\mathrm{Aa}}$ \\
\hline & 18 & $1.4^{\mathrm{Ab}}$ & $3.0^{\text {Abab }}$ & $1.0^{\mathrm{Ab}}$ & $4.6^{\mathrm{Aa}}$ & $1.8^{\mathrm{Ab}}$ & $1.2^{\mathrm{Ab}}$ \\
\hline & 36 & $1.0^{\mathrm{Ab}}$ & $5.8^{\mathrm{Aa}}$ & $1.0^{\mathrm{Ab}}$ & $2.0^{\mathrm{Bb}}$ & $1.2^{\mathrm{Ab}}$ & $2.0^{\mathrm{Ab}}$ \\
\hline \multirow[t]{4}{*}{ Macrophages } & Control & $0.0^{\mathrm{Aa}}$ & $0.4^{\mathrm{Aa}}$ & $0.2^{\mathrm{Aa}}$ & $0.0^{\mathrm{Aa}}$ & $0.2^{\text {Aa }}$ & $0.2^{\mathrm{Aa}}$ \\
\hline & 12 & $0.4^{\mathrm{Aa}}$ & $0.0^{\mathrm{Aa}}$ & $0.2^{\mathrm{Aa}}$ & $0.0^{\mathrm{Aa}}$ & $0.0^{\mathrm{Aa}}$ & $0.0^{\mathrm{Aa}}$ \\
\hline & 18 & $0.0^{\mathrm{Aa}}$ & $0.2^{\mathrm{Aa}}$ & $0.0^{\mathrm{Aa}}$ & $0.0^{\mathrm{Aa}}$ & $0.2^{\mathrm{Aa}}$ & $0.0^{\mathrm{Aa}}$ \\
\hline & 36 & $0.0^{\mathrm{Aa}}$ & $0.4^{\mathrm{Aa}}$ & $0.2^{\mathrm{Aa}}$ & $0.2^{\mathrm{Aa}}$ & $0.2^{\mathrm{Aa}}$ & $0.2^{\mathrm{Aa}}$ \\
\hline \multirow[t]{4}{*}{ Granulocytes } & Control & $0.0^{\mathrm{Aa}}$ & $0.0^{\mathrm{Aa}}$ & $0.4^{\mathrm{Aa}}$ & $0.0^{\mathrm{Aa}}$ & $0.2^{\mathrm{Aa}}$ & $0.0^{\mathrm{Aa}}$ \\
\hline & 12 & $0.0^{\mathrm{Aa}}$ & $0.0^{\mathrm{Aa}}$ & $0.2^{\mathrm{Aa}}$ & $0.0^{\mathrm{Aa}}$ & $0.0^{\mathrm{Aa}}$ & $0.0^{\mathrm{Aa}}$ \\
\hline & 18 & $0.2^{\mathrm{Aa}}$ & $0.0^{\mathrm{Aa}}$ & $0.0^{\mathrm{Aa}}$ & $0.0^{\mathrm{Aa}}$ & $0.0^{\mathrm{Aa}}$ & $0.0^{\mathrm{Aa}}$ \\
\hline & 36 & $0.2^{\mathrm{Aa}}$ & $0.4^{\mathrm{Aa}}$ & $0.0^{\mathrm{Aa}}$ & $0.4^{\mathrm{Aa}}$ & $0.2^{\mathrm{Aa}}$ & $0.4^{\mathrm{Aa}}$ \\
\hline
\end{tabular}

Means $(n=5)$ with at least one letter in common do not differ from each other through Tukey's test $(\mathrm{p}>0.05)$.

Analysis of variance is represented by capital letters in the columns for comparing the different treatments within each exudate variable, and lowercase letters in the lines for comparing the evolution of each treatment among the different periods. ( $S$ ) inoculated with saline solution and (B) inoculated with inactivated A. hydrophila. HPS-hours poststimulus.

In the present study, inoculation of the bacterium or even injection of saline solution seemed to be enough stimulation to cause stress, since the fish treated in this way presented high cortisolemia. Fish feed diet supplemented with $\mathrm{Cr}$ presented diminished cortisolemia, corroborating the findings of Fujimoto et al. (2005). The results showed that the plasma cortisol concentration was greater in fish fed with the chromium-free diet and lower in those fed diets supplemented with chromium carbochelate, thus suggesting that this mineral may have an anti-stress effect.

The glycemia determinations showed that, at least to some extent, the fish that received supplementation with chromium carbochelate presented lower glycemia. However, other authors did not observe this reduction in models that used high stocking densities for the same species of fish in situations of chronic stress (Belo et al., 2005, 2012; Fujimoto et al., 2005). This difference can be explained by the effects of glucocorticoids, which are more easily observed under acute stress conditions because during the chronic stress, uptake and consumption of glucose reserves reduce the effects of mobilization through the processes of glycogenesis and neoglycogenesis (Mommsen et al., 1999).

In the present assay, the stress caused by the inflammation was acute and was evaluated some hours after its induction. This made it possible to observe the variation of cortisolemia and glycemia. Variation in the latter may be a consequence of the former (Belo et al., 2005, 2012; Fujimoto et al., 2005), but may also be influenced by the boosting factor of the insulin, determined by chromium carbochelate. This, as a glucose tolerance factor (Mowat, 1997), facilitates the chemical interaction of insulin with its receptor on cell membranes, and produces increased cell sensitivity (Lukaski, 2000; Mertz and Roginski, 1969), increased uptake of plasma glucose and diminished glycemia, as suggested by the result observed at the concentration of $36 \mathrm{mg} \cdot \mathrm{kg}^{-1}$ at $48 \mathrm{~h}$ after stimulation.

In the present assay in which inflammation was induced by inactivated $A$. hydrophila, which was an antigenic stimulus, the presence of lymphocytes at the inflamed focus of the fish that received or did not receive chromium carbochelate was observed. Lymphocytes are always present in acute inflammation induced by non-antigenic agents such as carrageenan or thioglycolate, or by antigenic substances, although their functions are yet not well understood, either in fish or in mammals (Bozzo et al., 2007; Claudiano et al., 2013; Martins et al., 2008, 2009; Reque et al., 2010; Salvador et al., 2012).

Since the stimulus with $A$. hydrophila is of antigenic nature, the presence of lymphocytes in both groups is likely to have originated from the functions of $\mathrm{B}$ and $\mathrm{T}$ cells, which are responsible for the specific recognition of pathogenic agents and for the beginning of the adaptive immune response. B lymphocytes proliferate and differentiate into memory cells or IgM-producing plasmocytes. In addition, they have phagocytic activity and form phagolysosomes with microbicidal action. T cells act as memory cells and persist after the infection (Randelli et al., 2008).

As well as lymphocytes, thrombocytes are present in acute inflammation induced by non-antigenic agents such as carrageenan or thioglycolate, or by antigenic substances (Claudiano et al., 2013; Martins et al., 2009; Reque et al., 2010; Salvador et al., 2012). In the present assay, these cells were observed at the inflamed focus of both the supplemented and the unsupplemented fish. However, in those supplemented with $18 \mathrm{mg} \mathrm{Cr} \cdot \mathrm{kg}^{-1}$ they were seen to have accumulated in greater amount at $24 \mathrm{~h}$ after stimulation, thus suggesting that there were some beneficial effects from supplementation for developing the inflammatory function.

The greater accumulation of thrombocytes in the groups supplemented with 18 and $36 \mathrm{mg} \mathrm{Cr} \cdot \mathrm{kg}^{-1}$ of feed, at $6 \mathrm{~h}$ after stimulation, and with $18 \mathrm{mg} \mathrm{Cr} \cdot \mathrm{kg}^{-1}$ of feed, may have been due to the interaction between chromium and insulin receptors. This leads to an increase in the availability of intracellular glucose (Lukaski, 2000), thus facilitating cell events of inflammatory response given that it favors the action of insulin and reduces cortisolemia (Moraes and Garcia-Leme, 1982).

These results together suggest that food supplementation with chromium carbochelate, at the concentrations of 18 and $36 \mathrm{mg} \cdot \mathrm{kg}^{-1}$ of feed, brought homeostatic benefits to P. mesopotamicus. These benefits were translated, at least partially, as reductions in the consequences from inflammatory stress, with diminished cortisolemia and glycemia, which favored accumulation of lymphocytes and thrombocytes at the affected focus, as an increase in the immune response.

\section{Acknowledgments}

To the São Paulo Research Foundation (FAPESP) for the financial support (05/57989-8). The authors thank CNPq (Conselho Nacional de Desenvolvimento Científico e Tecnológico) for financial support to F.R., Moraes and J.R.E. Moraes.

\section{References}

Barton, B.A., Iwama, G.W., 1991. Physiological changes in fish from stress in aquaculture with emphasis on the response and effects of corticosteroids. Annu. Rev. Fish Dis. 1, 3-26.

Belo, M.A.A., Schalch, S.H.C., Moraes, F.R., Soares, V.E., Otoboni, A.M.M.B., Moraes, J.R.E., 2005. Effect of dietary supplementation with vitamin $\mathrm{E}$ and stocking density on macrophage recruitment and giant cell formation in the teleost fish, Piaractus mesopotamicus. J. Comp. Pathol. 133, 146-154.

Belo, M.A.A., Moraes, J.R.E., Soares, V.E., Martins, M.L., Brum, C.D., Moraes, F.R., 2012. Vitamin $C$ and endogenous cortisol in foreign-body inflammatory response in pacus. Pesq. Agrop. Bras. 47, 1015-1021.

Belo, M.A.A., Moraes, F.R., Yoshida, L., Prado, E.J.R., Moraes, J.R.E., Soares, V.E., Silva, M.G., 2014. Deleterious effects of low level of vitamin $\mathrm{E}$ and high stocking density on the hematology response of pacus, during chronic inflammatory reaction. Aquaculture 422-423, 124-128.

Boyd, C.E., 1990. Water Quality in Ponds for Aquaculture, Alabama Agricultural Experiment Station, Auburn University, Auburn, Alabama.

Bozzo, F.R., Moraes, J.R.E., Moraes, F.R., Pereira, G.T., Tavares-Dias, M., Onaka, E.M., 2007. Kinetics of cellular component in inflammatory response induced by different stimuli in the swim bladder of Piaractus mesopotamicus, Holmberg, 1887 (characidae). J. World Aquacult. Soc. 38, 302-308. 
Castro, M.P., Claudiano, G.S., Petrillo, T.R., Shimada, M.T., Belo, M.A.A., MarzocchiMachado, C.M., Moraes, J.R.E., Manrique, W.G., Moraes, F.R., 2014a. Acute aerocystitis in nile tilapia bred in net cages and supplemented with chromium carbochelate and Saccharomyces cerevisiae. Fish Shellfish Immunol. 31, 284-290.

Castro, M.P., Moraes, F.R., Fujimoto, R.Y., Cruz, C., Belo, M.A.A., Moraes, J.R.E., 2014b. Acute toxicity by water containing hexavalent or trivalente chromium in native Brazilian fish, Piaractus mesopotamicus: anatomopathological alterations and mortality. Bull. Environ. Contam. Toxicol. 92, 213-219.

Claudiano, S.G., Petrillo, T.R., Manrinque, W.G., Castro, M.P., Loureiro, B.A., Marcusso, P.F., Belo, M.A.A., Moraes, J.R.E., Moraes, F., 2013. Acute aerocystitis in Piaractus mesopotamicus: participation of eicosanoids and pro-inflammatory cytokines. Fish Shellfish Immunol. 4, 01-06.

Fujimoto, R.Y., Castro, M.P., Moraes, F.R., Gonçalves, F.D., 2005. Efeito da suplementação alimentar com cromo trivalente em pacu, Piaractus mesopotamicus (Holmberg, 1887) mantido em diferentes densidades de estocagem. Parâmetros Fisiológicos. Bol. Inst. Pesca 31, 155-162.

Fujimoto, R.Y., Castro, M.P., Honorato, C.A., Moraes, F.R., 2007. Body composition and nutrient efficiency use by pacus fed on ration supplemented with chromium. Pesq. Agrop. Bras. 42, 1763-1768.

Fujimoto, R.Y., Castro, M.P., Moraes, F.R., Ramos, F.M., 2011. Chromium supplementation and stocking density in pacus. Rev. Cienc. Agra. 54, 172-177.

Garcia, F., Pilarski, F., Onaka, E.M., Moraes, F.R., Martins, M.L., 2007. Hematology of Piaractus mesopotamicus fed diets supplemented with vitamins $\mathrm{C}$ and $\mathrm{E}$, challenged by Aeromonas hydrophila. Aquaculture 271, 39-46.

Gazola, R., Bonella, M.I., Donaldson, E.M., Val-Sella, M.V., Moraes, F.F., Bernardino, G., 1996. Plasma steroids and corticosteroid levels in female pacu Piaractus mesopotamicus Teleostei-Characidae. Braz. J. Med. Biol. Res. 29, 659-664.

Littell, R.C., Henry, P.R., Ammerman, C.B., 1998. Statistical analysis of repeated measures data using SAS procedures. J. Anim. Sci. 76, 1216-1231.

Lukaski, H.C., 2000. Magnesium, zinc, and chromium nutriture and physical activity. Am. J. Clin. Nutr. 72, 585-593.

Martins, M.L., Miyazaki, D.M., Moraes, F.R., Giraldelli, L., Adamante, W.B., Mouriño, J.L. 2008. Ração suplementada com vitaminas C e E influencia a resposta inflamatória aguda em tilápia do Nilo. Cienc. Rural 38, 213-218.

Martins, M.L., Miyazaki, D.M.Y., Tavares-Dias, M., Fenerick Jr., J., Onaka, E.M., Bozzo, F.R., Fujimoto, R.Y., Moraes, F.R., 2009. Characterization of the acute inflammatory response in the hybrid tambacu (Piaractus mesopotamicus male $\times$ Colossoma macropomum female) (Osteichthyes). Braz. J. Biol. 69, 631-637.
Mertz, W., Roginski, E.E., 1969. Effect of chromium III supplementation on growth and survival under stress in rats feed low-protein diets. J. Nutr. 97, 531-536.

Mommsen, T.P., Vijaian, M.M., Moon, T.W., 1999. Cortisol in teleost: dynamics, mechanisms of action, and metabolic regulation. Rev. Fish Biol. Fish. 9, 211-268.

Moraes, F.R., Garcia-Leme, J., 1982. Endogenous corticosteroids and insulin in acute inflammation. Microvasc. Res. 23, 281-283.

Moraes, F.R., Moraes, J.R.E., Bechara, G.H., 1987. Effect of alloxan diabetes and adrenalectomy on carrageenin-induced pleurisy in the rat. Braz. J. Med. Biol. Res. 20, 47-53.

Mowat, D.N., 1997. Organic Chromium in Animal Nutrition, Chromium Books, Guelph, Ontario.

Popoff, M., 1984. Genus III Aeromonas Kluyver and van Niel 1936 398AL. In: Krieg, N.R., Holt, J.G. (Eds.), Bergey's manual of systematic bacteriology. Williams \& Wilkins, Baltimore, MD, pp. 545-548.

Prado, E.J.R., 2014. Insulin and dexamethasone on acute aerocistite induced by Aeromanas hydrophila in Nile tilapia, Oreochromis niloticus, alloxan-diabetic. Thesis of Master , São Paulo State University, Jaboticabal, São Paulo State, Brazil (76 pp.).

Randelli, E., Buonocore, F., Scapigliati, G., 2008. Cell markers and determinants in fish immunology. Fish Shellfish Immunol. 25, 326-340.

Reque, V.R., Moraes, J.R.E., Belo, M.A.A., Moraes, F.R., 2010. Inflammation induced by inactivated Aeromonas hydrophila in Nile tilapia fed diets supplemented with Saccharomyces cerevisiae. Aquaculture 300, 37-42.

Sakabe, R., Moraes, F.R., Belo, M.A.A., Moraes, J.E.R., Pilarski, F., 2013. Kinects of chronic inflammation in Nile tilapia supplemented with essential fatty acids n-3 and n-6. Pesq. Agrop. Bras. 48, 313-319.

Salvador, R., Toazza, C.S., Moraes, J.R.E., Moraes, F.R., 2012. Inflammatory responses of Nile tilapia Oreochromis niloticus to Streptococcus agalactiae: effects of vaccination and yeast diet supplement. Dis. Aquat. Org. 98, 235-241.

SAS Institute Inc., 2001. SAS/STAT software changes and enhancements through compute program. Release 8.2, SAS Institute, Cary.

Snedecor, G.W., Cochran, G., 1974. Statistical Methods, Iowa State University Press, Ames.

Wedemeyer, G.A., 1997. Effects of rearing conditions on the health and physiological quality of fish in intensive culture. In: Iwama, G.K., Pickering, A.D., Sumpter, J.P. Schreck, C.B. (Eds.), Fish Stress and Health in Aquaculture. Cambridge University Press, USA, pp. 35-71. 